\title{
Katılımcı Sanatın Dönüştürücü Etkisi: Kadınların Tiyatro Deneyimi Üzerinden Betimleyici Bir Çözümleme
}

\author{
The Transformative Impact of Participatory Art: A Descriptive Analysis on \\ Women's Theater Experience
}

\begin{abstract}
Merih TAŞKAYA*
Öz: Öncelikli olarak kadınların katılımını hedefleyen katılımcı sanat çalışmaları, kadınlara kendi sorunlarına ilişkin farkındalık kazanmaları için olanaklar sunarken, aynı zamanda kendilerini gerçekleştirme ve ifade edebilme alanları sağlayabilmektedir. 2010 yılında Antalya'da öncelikle dezavantajlı bölgelerde yaşayan ev kadınlarının katılımını hedefleyerek hayata geçirilen ve halen devam eden "Kadınlar Tiyatroyla Buluşuyor" adlı proje, bir "katılımcı sanat" projesidir. Projede, kadınların, sorunlarını, umutlarını, korkularını, beklentilerini toplumla paylaşabilecekleri bir ortam olarak tiyatro sahnesini kullanmalarını sağlamak hedeflenmiştir. Proje, kadınların kendi yaşadıkları sorunlardan yola çıkarak yazdıkları öykülerini senaryolaştırma ve sahne sanatlarına yönelik beceri kazandırma etkinliklerini içermektedir. Proje katılımcısı kadınların önemli bir kısmı, kentin -sosyal ve ekonomik açıdan- dezavantajlı bölgelerinde yaşayan ev kadınlarıdır. 2010-2017 yılları arasında üçü katılımcı kadınlar tarafından yazılan dört ayrı oyun, yurtiçinde kırk bir, yurt dışında bir defa, katılımcı kadınlar tarafından sahnelenmiştir. 34 katılımcı kadın arasından derinlemesine görüşme yapılan 13 kadın projeye halen devam etmektedir. Bu 13 kadın, 2011 ve 2015 yıllarında yapılan derinlemesine görüşmelerde, kendilerini ifade etme becerilerindeki gelişmeyi dile getirmişler ve tiyatro projesini bir özgürlük alanı olarak niteleyerek proje sürecinde özgürleştiklerini ifade etmişlerdir. Bu çalışmada, kadınların özgürlük algılarının sosyolojik analizi, şu anda projeye devam eden kadınlarla 2011 ve 2015 yıllarında yapılan görüşmelerdeki ifadeleri üzerinden yapılmış ve özgürlük algıları Bauman'ın toplumsal bir ilişki olarak analiz ettiği özgürlük yaklaşımı kapsamında değerlendirilmiştir.
\end{abstract}

Anahtar sözcükler: Toplumsal Cinsiyet, Kadın Mücadelesi, Katılımcı Sanat, Tiyatro, Zygmunt Bauman

\begin{abstract}
Participatory art studies that primarily target women's participation can provide opportunities for women to gain awareness of their own problems while at the same time providing areas for realizing and expressing themselves. The project entitled "Women Meet the Theater", which was initiated in Antalya in 2010 aiming at the participation of housewives especially living in disadvantaged areas, is a "participatory art" project. In the project, it was aimed to use the theater scene as an environment where women can share their problems, hopes, fears and expectations. The project consists of screenwriting stories written by women from their own problems and gaining skills for performing arts. A significant number of project participants women are housewives living in disadvantaged areas of Antalya in terms of social and economic aspects. The four plays, three of them were written by themselves, were staged by these women, forty times in the country and once abroad by participating women, between 2010-2017. Of the 34 participating women, 13 women who had in-depth interviews are still in the project. In 2011 and 2015, 13 women interviewed by in-depth interviewing techniques expressed their progress in expressing their skills and expressed their experience of freedom in the process of theater project, which they regard as a field of freedom. Women's perceptions of freedom were assessed within the scope of the freedom approach that Bauman analyzes as a "social relationship".
\end{abstract}

Keywords: Gender, Women's struggle, Participatory art, Theater, Zygmunt Bauman

\footnotetext{
* Doç. Dr., Akdeniz Üniversitesi, Halkla İlişkiler ve Tanıtım Bölümü, Antalya. meriht@ akdeniz.edu.tr
} 


\section{Giriş}

Çeşitli söylenlerle kutsanıp kadın için mabet haline getirilen "ev içi”" toplumsal cinsiyete dayalı ayrımcılığın sürekli yeniden üretildiği bir alan olmaya devam etmektedir. Bu kutsama hali, kadının varlık nedenini aileye indirgerken, aile içi iş bölümü kadını eve, erkeği kamusal alana demirlemektedir. İnsanların cinsel kimliği kapsamında çizilen toplumsal rollerin katı sınırlar çerçevesinde dayatıldığı toplumsal yapılarda, bu roller aynı zamanda özgürlüğün sınırlarını da belirlemektedir. Bauman (2012a, 83-84), cinsiyete dayalı toplumsal rollerin, yazg1 olarak içselleştirilmesi durumunda insanların özgürlük alanlarını belirleme yetileri üzerindeki baskılayıcı etkisini anlatırken, "bu değişmez yazglyı kişinin vazifesi yapan bir yaşam sürmeye mecbur olup olmadiğı" sorusuna verilecek yanıtın önemli olduğunu vurgular. Ev içi işleri kadının yazgısı haline getirip doğal vazifesi olarak içselleştirilmesine neden olan cinsiyete dayalı toplumsal iş bölümünün bu noktada sıkılıkla masaya yatırılması gerekmektedir.

Değer ölçütü olarak somut değerin, yani ücretin konumlandırılması, modernitenin yarattığı kabuller arasındadır ve kolayca değişmesi beklenemez. Kadının hanedeki -ücretsiz- emeğinin, kadının haneye katkısını değersizleştirmesinin nedenlerinden birisi de budur. Kamusal alandaki emeği karşılığında aldığı ücret ve edindiği saygınlık sayesinde erkek; baba, koca, evin reisi olarak eşi dâhil, tüm aile üyeleri üzerinde otorite sahibi olarak görülür (Taşkaya 2013). Otorite sahipliği, diğer sahiplik ilişkilerinde olduğu gibi sahip olana, sahip olmayanların seçimlerini, kararlarını etkileme/belirleme gücü vermektedir. Bauman (2017, 144-145), bütün sahip olma biçimlerinin, sahip olanları bu anlamda da yetkinleştirdiğinden bahseder. Bu yetkinliği hane içindeki iktidar üzerinden okuyacak olursak, kadının özerkliğini, eylem ve seçimlerindeki özgürlügünü kısıtlayıcı etkilerin hane içindeki kaynağına işaret etmiş oluruz. Bauman, bütün sahiplik biçimlerinin altında yatan şeyin, ötekilerin haklarının benimkini kısıtlaması ya da benim özgürlüğümün genişlemesinin, ötekilerin özgürlüklerinin daraltılması ilkesinin kabulü olduğunu dile getirir. Bauman'a $(2017,145)$ göre bu durum kazananı olmayan bir oyundur, çünkü paylaşma ve işbirliği ile hiçbir şeyin kazanılmayacağı varsayılır. Hane içinde, erkeğin sahip olduğu otoriteden kaynaklı gücün gönüllü olarak kadınla paylaşılması erkek için güç kaybı anlamına gelir. Özel yaşam da, bu gücün erkeğin elinde kalmasına hizmet edecek biçimde düzenlenmiştir. Kadının kamusal alanda çalışarak varlık göstermesi, kısmen de olsa hanede gücün paylaşılması anlamına gelir. Bora (2004) da özel yaşamın düzenlenme biçiminin erkeklerin kamusal alana katılımını özendirirken, kadınların katılımında caydırıcı etkilere sahip olduğunu belirtir. Tüm bu caydırıcı etkilere karşın, kadınların özne olma deneyimini kamusal alanda yaşayabileceği olanakların yaratılması için, baskı gruplarının ısrarlı bir tavır içinde olmaları önemlidir. Ayn1 1srarc1 tavır, mevcut cinsiyet rollerini yeniden üreten odaklara da yönelmelidir. Everts'e (1998, 22 akt. Kanwar 1999, 351) göre, belirlenmiş cinsiyet rollerinin yeniden üretilmesine neden olan eğitim-öğretim programlarının ve projelerinin terk edilmesi bunun için en önemli adımdır. Türkiye'de kadınlara yönelik sosyalleşme, boş zaman değerlendirme ya da eğitim-öğretim amaçlı programların/projelerin, genellikle kadınların toplumsal cinsiyet rolleri doğrultusunda, el becerilerine dayalı, (daha çok örgü, nakış, kumaş/obje boyama) çoğunlukla zanaat olarak nitelendirilen alanlarda yürütüldüğü görülür. Bu yönelim, kadının sosyalleşmesini sağlayabilse de, genellikle toplumsal cinsiyet rollerini pekiştirici bir etki sahiptir. Tersi yönde çabaların sayısı ve yaygınlığı ise oldukça sınırlıdır. Kadınların kendilerini gerçekleştirebilecekleri, kendilerini ifade edebilecekleri pek çok alan varken, aile içi iş bölümündeki rollerini daha iyi yapabilecekleri alanlarda eğitim almaları şartıyla sosyalleşmeleri teşvik edilir. Cinsiyet politikalarının sürekliliği, mevcut toplumsal düzenin korunmasında yaşamsal önemdedir. Bu nedenle pek çok alanda kontrol altında tutulur. Bauman (2016, 19), toplumsal kontrolün sağlanması gereken durumlar için iki yoldan bahseder: İnsanın yapılması 
istenmeyen şeyleri yapmaktan alıkoymak birinci yol; yapılması istenen şeylerin yapılması için de teşvik etmek ikinci yoldur.

Kadınların belirlenmiş cinsiyet rollerine uygun davranmaları bir taraftan gelenekle, diğer taraftan bu tür eğitimler aracılığıyla sağlanır. Gelenek, bu noktada mahalle baskısı aracıllı̆ı ile panoptikondur. Gelenek bireyi gözetlendiği hissiyle yaşatır. Bauman (2016, 19-20), Foucault'un ustaca yorumladığı Panoptikon'un "modern gücün ıslah edici doğasına dair önemli bir kavrayış" sunduğunu belirtir. Tutsaklığı Panoptikon üzerinden açıklamaya yönelen Bauman'ın perspektifinden bakacak olursak, kadınların toplumsal rolleri nedeniyle hayatlarının büyük bir alanında geleneklerce tutuklu olmaları da benzer biçimde yorumlanabilir. Geleneksel rollerin modern eğitim kurumlarında -kurslar vd. aracılığı ile- kadınların üzerine tanımlı işler çerçevesinde sürdürülmesinde yaşanan evden azat olma durumu, kadınlar için şartlı tahliye gibidir.

Türkiye'de ve dünyanın pek çok yerinde kadının birincil görevi olarak algılanan ev işleri ve çocuk/yaşlı bakımı, kadının, zamanının ve enerjisinin oldukça büyük bir parçasını gasp eder. Gelenek aracılığı ile doğallaştırılan bu durum, kadın ve erkek arasındaki ilişki biçiminin geleneksel çizgiye paralel seyretmesine neden olur. Gelenek referansı, çoğu zaman kadına dünyanın diğer kapılarını kapatmış gibidir. Sanatsal alanın Türkiye'de kadınların yeterince temsil edilemediği alanlardan bir tanesi olmasının tarihsel arka planında da aynı referansı görmek mümkündür. Öte yandan, erkek hegemonyasının hüküm sürdügü sanatsal alanda, kadın imgesinin sunumunun sorunlu olduğunu da göz ardı etmemek gerekir. Bu noktada, kadının yeterince katılamadığ 1 sanatsal alanda, kadın imgesinin cinsiyete dayalı geleneksel rollere uygun konumlandırıldığını ve cinsiyetler arasında yaratılan ayrımcılığı yeniden ürettiğini vurgulayan çalışmalar oldukça değerlidir. Bu çalışmaların özellikle vurguladığı nokta, ideoloji üreten tüm alanlar gibi sanat alanının da kadına yönelik ayrımcılığın pekiştirildiği zeminin hazırlanmasından sorumlu olduğudur: Sanatsal alandaki eril hâkimiyet, kadın imgesini sanat ürünlerinde eril bir gözle konumlandırmakta, bu konumlandırma genellikle toplumsal cinsiyete dayalı roller çerçevesinde yapılmaktadır. Böylelikle sanat, etkileyici gücüyle, cinsiyet ayrımcılığının doğallaştırılmasında ve tırmandırılmasında çarpan etkisine sahip bir araç haline gelmektedir. Bu nedenle kadınların sanatsal alanlardaki varlıklarıyla kendi imgelerini konumlandırma şansına sahip olması önemlidir.

Sahne sanatlarının, insan potansiyelini doğrudan izleyicisine aktarma olanağına sahip olması ve gerçekliğe yakın canlandırma/temsil etme gücü nedeniyle etki yaratma olasılığının/ inandırıcılığının görece yüksek olduğu söylenebilir. Yamaner'in geleneksel tiyatrodan bugüne dek tiyatro sanatı aracıllğ̆ ile sunulan cinsiyetçi imgelem çerçevesinde, Türkiye'de sahnelenen yerli oyunlarda kadın karakterlerin kuruluşu ve sunumuna odaklandığı çalışmasında, tarihsel süreç içerisinde tiyatro sahnesinden yansıyan cinsiyetçi tutumu açıkça ortaya koymuş, kadının sahnede yer alabilmesi için vermek zorunda kaldığı mücadeleye dikkat çekmiştir:

Antik Yunan tiyatrosunda kurulan cinsiyetçi yap1, kadın karakteri nasıl ikincil konumda tutmuş ve nasıl kadına tiyatro sahnesini yasaklamışsa ve bu yasak ünlü Shakespeare dönemi tiyatrosunun sonlarına dek acımasızca nasıl devam etmişse, bizim tiyatro geleneğimizde de kadın karakterin yasakları delmesi ve giderek özne konumuna yükselebilmesi uzun ve sancılı bir süreci gerektirmiş̧ir (Yamaner, 2011, 681).

Kadın mücadelesini sokağa taşıyan gösteriler, mücadelenin canlı kalmasını sağlar, ancak Bora'nın dediği gibi gösteri, eylemin sadece bir parçasıdır, tamamı değildir. Bora'nın önerisi, gösteri kadar çekici ve gösterişli olmayan uzun soluklu çabalara girişilmesidir: "Yani bir kadınla konuşmak, bir başkasının hayallerini dinlemek, bir mahallede danışma merkezi açabilmek için uğraşmak... gerçek dokunmaları, ilişkileri, dönüşümleri mümkün kılan şeyler" (Bora 2011, 65). 
Öte yandan elbette hem katılımı sağlayacak kadar cazibeli hem de gerçek dokunmaları, dönüşümleri mümkün kılan girişimlerin bir arada olması mümkündür.

Kadınlara yönelik sosyal programlarda/projelerde sahne sanatlarının konumlandırılmasının, kadının sahnedeki varlığını kısıtlayan geleneksel dayatmaların kırılmasında etkili olabileceği beklenebilir. Ayrıca kadınların yaşadığı sorunların kitlelere duyurulabilmesi için sahnenin kullanılması etkili bir yol olarak değerlendirilebilir. Katılımcı sanat projeleri, -konumuz özelindekadınların sorunlarını kendi ağızlarından dile getirebileceği girişimler olarak ele alınmalıdır.

Sosyal bilimciler, sanatsal etkinliklerin toplumsal alanda yarattı̆̆ dönüştürücü etkileri gözlemlemeye devam etmektedir. Katılımcı sanat çalışmalarının, gerek sanatsal alanda gerekse sosyal sorumluluk çalışmaları kapsamında, sayıca artması ve yaygınlaşması sosyal bilimcilerin bu alana duyduğu ilgiyi artırmış görünmektedir. Matarasso (1997), kanıtların genellikle sanatsal katılımın, güven artışı, zengin sosyal ağlar, ya da yeni bilgi ve beceriler edinme gibi bir dizi kişisel fayda sağlayarak insanların esenliğine geniş katkıda bulunduğunu gösterdiğinden bahsetmektedir. Her ne kadar Bauman $(2016,52)$, modern özgürlüklerin filizlendiği seraların ortaçağda inşa edildiğini söylese de, katılımcı sanat projeleri aracılığı ile en azından kadınlar için özgürlük deneyiminin yaşandığı alanların inşa edilmesi sağlanabilir. Kadın sorunlarının çözümü için yürütülen çabaları destekleyecek bu tür girişimler, kadınlara özgürlüğü anlatmaktan daha motive edici olabilir.

Katılımcı sanatın ayırıcı bir alan olarak ortaya çıkışı, birçok bilim adamının savunduğu gibi, en azından modern dönemde görülen öncüllerine dayanmaktadır. Bu konuda yapılmış güncel çalışmalara göre, katılımcı sanat girişimlerinin kökleri, Avrupalı ve Latin Amerikalı avangartlardan yola çıkılarak, 1960'larda feminizmin katılımcı politikaları ve sivil haklar hareketi bağlamında, global olarak ise yirminci yüzyılda, performans sanatları ve tiyatro alanında yaşanan yeniliklerde aranmalıdır (Kelly 2014).

Kelly'nin ifadesine göre, katılımcı sanat, etkileşimli, ilişkisel, kooperatif, aktivist, diyalojik ve topluluk temelli sanat da dâhil olmak üzere, çakışan başlıklar altında tanımlanmaktadır. Bazı durumlarda, bir dizi katılımc1 insan tarafından sanat eseri yaratır; diğerlerinde ise katılımc1 eylemin kendisi sanat olarak tanımlanır. Kuşkusuz, kolektif sanat yaratımına katılım yeni değildir. Dünyanın dört bir yanında, tarih boyunca insanlar, geleneksel müzikten dansa, toplum festivallerinden duvar sanatlarına kadar pek çok alanda sanat yaratımına katılmışlardır (Kelly 2014). Sanatın insanları bir araya getirebilme gücünden ve rehabilitasyonda kullanımına ilişkin tarihsel örneklerden yola çıkan girişimler, katılımcı sanatın toplumsal sorunların gündeme getirilmesi için de kullanılabileceğini göstermektedir. Dünyada bu amaçla yürütülmüş pek çok katılımcı sanat projesi örneği vardır. Bu çabaların katılımcılarındaki iyileştirici etkileri de çeşitli çalışmalarla sunulmuştur (bk. Taşkaya 2013; Hacking et al. 2016). Bu projelerin ortak özellikleri sanatçı veya sanat kolektifine ek olarak insanların katılımıyla yaratılmış olmalarıdır. Katılımcı sanatta, sıradan insanlar, topluluk üyeleri ya da sanatçı olmayan kişiler, eserleri yaratmak için profesyonel sanatçılarla etkileşime girerler (Kelly 2014).

Antalya'da kadınların, sorunlarını, umutlarını, mutluluklarını, korkularını, beklentilerini toplumla paylaşabilecekleri bir ortam olarak tiyatro sahnesini kullanmalarını sağlamak üzere, kendi yaşadıkları sorunlardan yola çıkarak yazdıkları öykülerini senaryolaştırma ve sahne sanatlarına yönelik beceri kazandırma etkinliğini içeren Kadınlar Tiyatroyla Buluşuyor adlı proje de bir katılımcı sanat projesi niteliğindedir. 2010 yılında Antalya Büyükşehir Belediyesi'nin desteğiyle başlayan proje, 2014 yılından itibaren projeye yöneticisinin girişimleriyle kurulan Antalya Kadın Sahnesini Destekleme Derneği tarafından desteklenmekte ve hala devam etmektedir. Dernek 08.04.2011 tarihinde, proje katılımcısı kadınların üyeliği ile Antalya'da kurulmuş- 
tur. Derneğin yönetim kurulu da yine proje katılımcısı kadınlardan oluşmaktadır.

\section{Kadınlar Tiyatroyla Buluşuyor Projesi}

Türkiye'de, kadın sorunlarına yönelik mücadele alanlarına, sorunlarla doğrudan ve sıklıkla karşılaşan kadınların aktif katılımını sağlayan pratik temelli çalışmalara nadiren rastlanmaktadır. 2010 yılında Antalya'da, öncelikle sosyal ve ekonomik açıdan dezavantajlı, kent merkezinden uzak bölgelerde yaşayan ev kadınlarının katılımını hedefleyerek hayata geçirilen ve halen devam eden Kadınlar Tiyatroyla Buluşuyor adlı proje, bu nadir örneklerden birisidir.

Katılımcı sanat projeleri sosyal sorunları odağına aldığ zaman, katılımcı kitlesini de amaca dayalı olarak belirlemektedir. Kadınlar Tiyatroyla Buluşuyor projesinde de katılımcı kitle, projenin amacı doğrultusunda belirlenmiştir. Proje katılımcısı otuz dört kadının önemli bir kısmı dezavantajlı bölgelerde yaşayan, daha önce bu tür bir faaliyete katılmamış ev kadınlarıdır. Katılımcı kadınlar arasında, daha önce çalışma hayatında yer alan ve emekli olan kadınlar da vardır. Proje, her ne kadar dezavantajlı bölge kadınlarını öncelikli olarak hedeflemiş olsa da, gelen katılım talepleri üzerine -kadın olmanın dezavantajlı durumunu göz önüne alarak- kent merkezine yakın ikamet eden, sosyal hayata katılımı görece daha fazla olan kadınları da kapsamıştır. Proje, başladığı 10 Ocak 2010 tarihinden, 30 Mart 2014 tarihine kadar Antalya Büyükşehir Belediyesi Tiyatrosu'nun yönetmeninin ve oyuncularının yanı sıra sahne sanatları kapsamında faaliyet gösteren bir özel sanat kuruluşunun gönüllü katılımı ile sürdürülmüştür. Proje, 2014 yerel seçimlerinde Antalya Büyükşehir Belediyesi yönetiminin değişmesi sonrasında, Antalya Kadın Sahnesini Destekleme Derneği tarafından desteklenerek yürütülmeye devam etmiştir.

Proje başlangıcında katılımcılara oyunculuk için gerekli temel çalışmalar üç ay boyunca profesyonel yönetmen ve oyuncular tarafından gönüllü olarak yaptırılmıştır. Katılımcı kadınlar arasında yer alan bir kadının gerçek yaşam öyküsünden bir kesit, yine aynı kadın tarafından yazılmış, yönetmenin desteğiyle senaryolaştırılmış ve 8 Mart 2010 yılında "Bir evet İki Hayır Arasında Hayat" adıyla katılımcı kadınlar tarafından sahnelenmiştir. İkinci oyun, katılımcı kadınlardan biri tarafından hazırlanmış, yine yönetmen desteği ile senaryolaştırılmıştır. Üçüncü oyun, ilk iki oyundan farklı olarak katılımcı kadınların yazdıkları öykülerin birleştirilmesi ile hazırlanmıştır. "Çekiyorum Gülümseyin" adlı bu oyunun yazım aşaması öncesinde kadınlara, Devlet Tiyatroları'ndan kondüvit olarak çalışan profesyonel bir senarist, bir ay boyunca gönüllü olarak senaryo yazım atölyesinde eğitim vermiştir. Bu oyun Nürnberg Belediyesi'nin daveti üzerine, 2014 yılında Nürnberg'de sahnelenmiştir. Dördüncü oyun ise kadın öykülerini konu olan, profesyonel oyun yazarlarınca yazılmış iki ayrı oyunla kadınların kendi öykülerinin birleştirilmesiyle hazırlanan "Kimim Ben?" adlı oyundur. Bu oyun halen sahnelenmeye devam etmektedir. Proje kapsamında sahnelenen oyunlardan ilki hariç tümü skeçlerden oluşturulmuş, birbirinden bağımsız sahneler ve süreksiz roller aracılığı ile katılımcı kadınların tümünün oyunlarda rol alması sağlanmıştır. Bütün bir öyküyü içeren ilk oyunda ise, yine tüm katılımcıların rol alabilmesi için senaryoya yeni karakterler eklenmiştir. Oyunlar açık biçim seyirlik oyunlar olarak tasarlanmış, böylece seyirci ile etkileşim güçlü tutulmuştur. Sahneler ortaoyununda olduğu gibi bir anlatıcı ile birbirine bağlanmıştır. Oyunların tümünde kadın sorunları konu edilmiştir. Konunun kadın sorunları odağında kalması, olay bazında kimi zaman güncel kadın sorunlarının doğaçlama olarak sahnede dile getirilmesiyle; çoğu zaman da olgu bazında temel sorunların senaryoda yer almasıyla sağlanmıştır.

2010-2017 yılları arasında, üçü kendileri tarafından yazılan, dört ayrı oyun yurt içinde kırk iki, yurt dışında bir defa katılımcı kadınlar tarafından sahnelenmiştir. Projeye katılan kadınların 
yaş ortalamaları, 2010 yılı itibariyle 46; 2015 yılında ise 58'dir.

\section{Yöntem ve Örneklem}

Kadınlar Tiyatroyla Buluşuyor Projesi katılımcıları ile ilk görüşmeler kadınların temelde projeden beklentilerini ve o ana kadarki kazanımlarını belirlemek amaciyla 2011 yılının mayıs ve haziran aylarında, yarı yapılandırılmış görüşme formları kullanılarak ve kayıtlı-izinli olarak yürütülmüştür. Görüşmeler projeye katılan 34 kadından 33'ü ile yapılmıştır. Katılımcılardan bir tanesi ile (Görüşmeci 13), görüşme tarihi öncesinde projeden ayrılmış olduğu için görüşme yapılmamıştır. Bu görüşmelerden elde edilen veriler, proje kapsamında değerlendirilmiş, elde edilen bulgular proje sürecinin iyileştirilmesi amacıyla kullanılmıştır.

2010 ile 2015 yılları arasında projeye katılan kadınların sayısında azalma gözlenmiştir. Y1llara göre katılımcı sayısı 2010 yılında 34, 2011 yılında: 34, 2012 yılında 30, 2013 y1lında 24, 2014 yılında 22 ve 2015 yılında 13'tür. 2010-2015 yılları arasında proje katılımcısı 34 kadından 22'si projeden ayrılmış, -projeden ayrılan 22 kadından 5'i eğitim hayatlarına devam etmek için, 3'ü işe başlama nedeniyle, 2'si ebeveynlerinin bakımı nedeniyle, 4'ü sağlık sorunları gerekçesiyle, 7'si grup içi çatışmalar nedeniyle ve 1'i ise şehir değiştirmesi nedeniyle proje dışında kalmıştır- 1 kadın ise projeye 2012 yılında katılmıştır. 2015 yılında, katılımcı sayısı 13'e düşmüştür. 13 kadın projeye halen devam etmektedir. Bu çalışmada, 13 kadının projeye devam etmesinin nedenleri, aynı zamanda projeden elde edilen kazanımlar olarak varsayılmış ve ayrılanların projeden kazanımları konusundaki ifadeleri "çevrelarkadaş edindim", "empati yeteneğim arttı", "daha hoşgörülü oldum", "eğlendim", "deneyim oldu” gibi pek çok farklı odağa yayılırken, projeye devam eden kadınların gerekçelerinin odak ortaklığı dikkat çekici bulunmuştur: Ortak gerekçe, “özgürlük” kavramı çerçevesindedir. 2011 y1lında yapılan derinlemesine görüşmelerden elde edilen verilerin analizi sonucunda ortaya çıkan bulgular gözden geçirildiğinde, 2015 yılı itibariyle projeye devam eden kadınların "projenin size kazandırdığı en önemli şey nedir?" sorusuna -projeden ayrılan kadınların pek çoğundan farklı olarak- "özgürlük" kavramı temelinde yanıtlar verdikleri görülmüştür. 2011 y1lında görüşmeye katılan 33 kadından 15 'i projeyi bir özgürlük alanı olarak değerlendirmiş ve bu proje sırasında özgürleştiklerini ifade etmişlerdir. 2011 yılında yapılan derinlemesine görüşmede, projenin kendilerine özgürlük alanı sunduğunu söyleyen ancak sağlık sorunları nedeniyle 2014 yılında projeden ayrılmak zorunda kalan 2 kadın, fiilen projede yer almasalar da seyirci organizasyonu, çalışma alanı planlaması, kostüm gibi konularda projeye destek olmaya devam etmişlerdir.

$\mathrm{Bu}$ bulgu, katılımcı kadınların proje sürecinde özgürleştiklerine ilişkin ifadelerinden yola çıkılarak özgürlük algılarının kapsamının değerlendirilebileceği ikinci bir derinlemesine görüşme yapılmasını gerektirmiştir. Katılımcı kadınların kendi özgürlüklerine ilişkin algılarını konu alan bu çalışmada Kadınlar Tiyatroyla Buluşuyor projesine 2010 yılında katılan kadınlarla 2011 y1lında yapılan görüşmelerden elde edilen veriler, temel veri olarak değerlendirilmiştir. 2011 yılında yapılan görüşmelerde sorulan en temel soru "projeden kazanımınız ne oldu?" sorusudur. Bu soruya verilen yanıtlar, kadınların projeye devam etme gerekçeleri olarak kabul edilmiştir. Bu nedenle 2015 yılında projeye devam eden 13 kadınla yapılan görüşmede da aynı soru sorulmuştur. 2015 yılının Aralık ayında projeye devam eden 13 katılımcı kadınla, yarı yapılandırılmış görüşme formları kullanılarak ve kayıtl1-izinli olarak ikinci görüşme gerçekleştirilmiştir. Bu görüşmede katılımcılara, "bu projede kazandiğınız en önemli şey nedir?", "bu proje biterse nasll hissedersin?" ve "sizce özgürlük nedir?" soruları yöneltilmiştir. (Özgürlük konulu soru, kazanımlarını "özgürlük" kavramıyla dile getirmelerinden sonra, görüşme esnasında sorulmuştur. Yarı yapılandırılmış görüşme formunda bu soru yer almamaktadır). 
Bu çalışma, verileri 2011 ve 2015 yıllarında gerçekleştirilen iki ayrı görüşme ile toplanan, nitel bir çalışmadır. 2015 yılında sadece projeye devam eden 13 kadınla görüşme yapılmış, kadınların 2011 ve 2015 yıllarındaki ifadelerinin karşılaştırılabilir kılınması amacıyla, 2011 yılında 33 kadınla yapılan görüşmeler arasından sadece 2015 yılı itibariyle projeye devam eden 12 kadınla gerçekleştirilen görüşmeler bu çalışmada örnekleme dâhil edilmiştir. 2011 yılında görüşme yapılan ve örnekleme dâhil edilen kadın sayısının 12 olması, 1 kadının görüşme tarihinden sonra (2012 y1lında) projeye dâhil olması nedeniyledir. Nitel çözümlemede bu katılımcının ifadeleri, yıl bazında karşılaştırmalı olarak sunulmamıştır.

Verilerin çözümlenmesinde, Miles ve Huberman nitel çözümleme modeli kullanılmıştır. Miles ve Huberman, verilerin toplanması aşaması sonrasında, dinamik bir çözümleme süreci öngörmektedirler. $\mathrm{Bu}$ süreçte "birbirini etkileyen eş zamanlı akışlar veya faaliyetler" olarak konumlandırdıkları üç temel bileşenden söz etmektedirler. Bunlar, (1) verilerin azaltılması, (2) verilerin sergilenmesi ve (3) sonuçların betimlenmesi ve doğrulanmasıdır (Punch 2014, 192). Bu çalışmada verilerin azaltılması süreci, çözümlemenin bir parçası olarak verilerin düzenlenmesi, bölümlenmesi ve özetlenmesi ile eşzamanlı yürütülmüştür. $\mathrm{Bu}$ aşamada temalar belirlenmiş, örüntüler tespit edilmiş ve bunlara bağlı olarak notlar alınarak, verilerden elde edilen kodlar oluşturulmuştur. Hacimli ve dağınık verilerin sunumu aşamasında, tablo ile görselleştirme tercih edilmiştir. Ancak kodlara bağlı olarak kategorize edilmiş ifadeler, metinde tırnak içinde italik harflerle veya paragraflar halinde italik harflerle sunulmuştur. Sonuçların biçimlendirilmesi ve doğrulanması, mantıksal olarak, veri azaltımı ve sunumu takiben gerçekleşse de aslında onlarla hemen hemen eş zamanlı yürütülür (Punch 2014, 193). Bu aşamada, araştırmanın konusu bağlamında Bauman'ın özgürlük yaklaşımı temel alınmıştır. Görüşmelerden elde edilen bulgular, Bauman'ın özgürlük yaklaşımı perspektifi ile değerlendirilmiştir.

2011 yılında yapılan görüşmede, "bu projeden elde ettiğiniz en önemli kazanım nedir?" sorusu çerçevesinde alınan yanıtlara bakıldığında, projeden ayrılan kadınların, gerekçelerinin içerikleri dağınıklık gösterirken; projeye devam eden 13 kadının ifadelerinde ortak bir tema tespit edilmiştir. Verilerin azaltılması aşamasında 2011 ve 2015 yıllarında yapılan görüşmelerde, projeye devam eden 13 kadının ifadelerindeki ortak olan temanın "özgürlük" olması nedeniyle analizde tema olarak "özgürlük" belirlenmiştir. "Kodlama bir taraftan çözümlemenin kendisi, diğer taraftan, çözümlemeyi başlatan belirli ve somut bir işlemdir... Kodlar; etikettir, isimdir veya nitelendirmedir ve bu nedenle kodlama, veri gruplartna etiketlerin, isimlerin veya nitelendirmelerin verilmesi işlemidir" (Punch 2014, 193-4). İlk düzey kodlamada, 2011 ve 2015 yıllarında yapılan görüşmelerdeki ifadelerden temalar oluşturulmuştur. Böylece veri kümeleri özetlenmiştir. Bunlar daha çok betimleyici kodlardır. Bu betimleyici kodlardan hareketle, 2011 ve 2015 yıllarında yapılan görüşmelerde ortak tema "özgürlük" olarak belirlenmiştir. İkinci düzey kodlama aşamasında özgürlük kavramının her iki görüşmede yer alan ifadeler aracılı̆̆ ile nitelendirmelerine odaklanılmıştır. Bu aşamada oluşturulan kodlar, "verilerden daha incelikli çıkarım yapmayı gerektiren daha yorumlayıcı" (Punch 2014, 193) kodlardır. Özgürlük kavramını işaret eden metaforlar ve doğrudan/açık söylemler, örüntü kodları olarak konumlandırılmıştır. "Örüntü kodu daha çıkarımsaldır ve bir tür 'metakod', yani değişmiş koddur" (Punch 2014, 193). Özgürlük teması çerçevesinde, örüntü kodları, tekrar sıklı̆̆ı esas alınarak: "kuş gibi olmak", "kanatlanıp uçmak", "benlik-ben olmak", "kimlik", "kişilik", "özgüven”, "kendini ifade etmek" olarak belirlenmiştir. Kodlama aşaması boyunca not alma işlemi devam ettirilmiştir. Bu notlara, kuramsal çerçeveden yaklaşımlar ve kişisel gözlemler de dâhil edilmiştir. Böylece yeni örüntülere ve üst düzey bir örüntü kodlamasına geçilmiştir. Miles ve Huberman'ın nitel veri çözümleme modelinde, sonuçların biçimlendirilmesi ve doğrulanması aşaması, kodlama ve not alma aşaması ardından elde edilen pek çok etiket ve not kümesinin 
anlamlı ve tutarlı bir veri görüntüsü içinde bütünleştirilmesini gerektirmektedir (Punch 2014, 196). Bu aşamada elde edilen ve tema, kodlar ve notlar aracılı̆̆ ile düzenlenen veriler, çalışmanın konusu itibariyle belirlenen Bauman'ın özgürlük yaklaşımı perspektifinde bütünleştirilerek sunulmuştur.

Bu çalışmada, Kadınlar Tiyatroyla Buluşuyor projesine katılan kadınlarla 2011 ve 2015 yıllarında yapılan iki ayrı derinlemesine görüşmenin nitel analizinde, kadınların ‘özgürlük' kavramı çerçevesinde verdikleri yanıtlara odaklanılmıştır.

Aşağıdaki tabloda 2011 ve 2015 yıllarında derinlemesine görüşme yapılan ve halen projeye devam eden katılımcı kadınların profillerine ilişkin bilgiler yer almaktadır. Görüşmeci kadınların kimlik bilgileri, gizlilik esası nedeniyle bu çalışmada kullanılmamıştır. Katılımcı kadınların isimleri yerine, görüşmeci numaraları kullanılmıştır.

Tablo 1: Görüşmeci Profiline İlişsin Temel Demografik Bilgiler

\begin{tabular}{|c|c|c|c|c|c|}
\hline Görüşmeciler & $\begin{array}{l}\text { Medeni } \\
\text { durum }\end{array}$ & $\begin{array}{l}2015 \text { yılı } \\
\text { itibariyle yaşı }\end{array}$ & $\begin{array}{l}\text { Çalışma } \\
\text { durumu }\end{array}$ & $\begin{array}{l}\text { İlk görüșme } \\
\text { tarihi (2011) }\end{array}$ & $\begin{array}{l}\text { İkinci görüşme tarihi } \\
\text { (2015) }\end{array}$ \\
\hline Görüşmeci 1 & evli & 55 & ev kadını & 10 May1s & 25 Aralık \\
\hline Görüşmeci 2 & evli & 54 & işçi & 14 Haziran & 25 Aralık \\
\hline Görüşmeci 3 & evli & 64 & ev kadını & 10 Mayıs & 25 Aralık \\
\hline Görüşmeci 4 & evli & 66 & ev kadını & 14 Haziran & 25 Aralık \\
\hline Görüşmeci 5 & evli & 49 & ev kadını & 14 Haziran & 25 Aralık \\
\hline Görüşmeci 6 & bekar & 58 & ev kadını & 10 Mayıs & 25 Aralik \\
\hline Görüşmeci 7 & evli & 52 & ev kadını & 10 Mayıs & 25 Aralik \\
\hline Görüşmeci 8 & evli & 59 & ev kadını & 10 Mayıs & 25 Aralık \\
\hline Görüşmeci 9 & evli & 65 & ev kadını & 10 Mayıs & 25 Aralık \\
\hline Görüşmeci 10 & bekar & 60 & ev kadını & 10 Mayıs & 25 Aralık \\
\hline Görüşmeci 11 & evli & 55 & ev kadını & 14 Haziran & 25 Aralık \\
\hline Görüşmeci 12 & evli & 57 & ev kadını & 10 Mayıs & 25 Aralık \\
\hline Görüșmeci 13 & evli & 55 & ev kadını & - & 25 Aralık \\
\hline
\end{tabular}

2015 yılında projeye devam eden 13 kadınla yapılan derinlemesine görüşmede, kadınlara bu projenin kendilerine katkısının ne olduğu tekrar sorulduğunda, yine "özgürlük" temelli yanıtlar alınmıştır. Kadınların, özgürlüğü, kendilerini ifade edebilecekleri bir alana sahip olma hali olarak nitelediklerine ilişkin yanıtlara sıklıkla rastlanmıştır. Bu çalışmada, 13 derinlemesine görüşme arasından araştırma konusuyla doğrudan ilişkili ve çarpıcı yanıtlar değerlendirilmiştir.

\section{Katılımcı Kadınların Özgürlük Algılarındaki Dönüşüm}

Bauman $(2017,29)$, aynı anda hem özgür olup hem de özgür olmama durumumuzu deneyimlerimizin en ortak ve muhtemelen en şaşırtıcı özelliği olarak değerlendirmekte, sosyoloji tarihinin de bu muammayı çözmeye niyetlenmiş pek çok çabayla dolu olduğunu belirtmektedir. Özgürlük, tanımlanarak çerçeve içine alınabilecek bir kavram olmaktan uzaktır; ancak deneyimlendiği anlarla ilişkili bir durum olarak nitelendirilebilir. Kaldı ki bu deneyim tüm belirlenmişliklerden azat edilmiş değildir: Beşeri düzlemde, tüm sosyal ve psikolojik baskılardan kurtulduğumuz bir an'ın deneyimlenebileceğini varsaysak bile, hem dışsal hem de içsel doğa tarafından belirlenmişliğimiz devam eder. $\mathrm{O}$ halde mutlak özgürlükten bahsetmek anlamlı olmadığı gibi özgürlügün ontolojik temellerine ilişkin bir tartışma, bu çalışmanın kapsamını da 
aşmaktadır. Bu çalışmanın özgürlüğü odağına almasındaki bir diğer neden, özgürlük arzusunun eyleme geçirici ya da eylemi sürdürücü etkisini vurgulamaktır.

Bauman $(2017,29,32)$ özgürlüğü "karar verme ve seçme yetisi" olarak tarif etmektedir. Ancak seçme özgürlüğünün kendi başına kişinin seçimlerini hayata geçirme, hele de bu seçimi yaparken niyet edilen sonuçlara ulaşma özgürlüğünü garanti etmeyeceğini de ekler: İnsanın özgür davranabilmesi için, özgür iradeden başka kaynaklara da ihtiyacı vardır. Bauman $(2000,82)$, bireysel seçimlere baskı yoluyla getirilen sınırlamalardan kurtulmanın, yani 'negatif özgürlüğün' insanlığın ulaşabileceği tek özgürlük olduğunu varsayarsak bile, bu özgürlüğün tek ya da en azından başlıca düşmanının, siyasi iktidarın aşırı yasa koyma/düzenleme hırsı olmadığ vurgular. Dolayısıyla, bu yasama müdahalelerinin siyasi iktidar tarafindan geri çekilmesinin de negatif özgürlügün sınırlarının genişletmeyeceğini belirtir. Örneğin kadınların çalışma hayatına katılmalarına izin veren -ya da tarihsel süreç içerisinde bunu teşvik eden- yasalar, kamusal alanda çalışma özgürlüğünün kadına geniş bir özgürlük alanı sağlayacağı iddiasına sahiptir. Söz konusu özgürlük olunca, elbette ücretli çalışma hayatı aynı zamanda -çoğunlukla- kamusal alanda yer alma anlamına gelir ve kadınların özgürlük algısında değişimi de beraberinde getirir. Ancak özgürlüğün salt ücretli çalışma hayatına katılım çerçevesinde algılanması sorunludur. Bu çalışma kapsamında yapılan görüşmelerde kadın sorunlarına ilişkin düşüncelerinin temelini özgürlük yoksunluğuna bağlayan kadınlar, ekonomik özgürlüğü daha az belirtmişlerdir.

2011 yılında yapılan görüşmede kadınların en temel sorunu olarak ekonomik özgürlüğü belirten kadınlardan, Görüşmeci-1, "(kadın) evde ekonomik özgürlüğü olmayınca bir yere gidemiyor. Erkeğe bă̆ıml oluyor. Erkek istediği yere gönderiyor istemediği yere göndermiyor" derken, 2015 y1lında yapılan görüşmede özgürlüğe ilişkin düşüncesini, "özgürlük, kendini ifade etmek bence, burada onu başarabiliyorum. (...) Proje biterse özgürlüğümü kaybederim” cümleleriyle dile getirmiştir.

Ekonomik özgürlüğü kadın sorunları arasında ilk sıraya koyan kadınlardan bir diğeri olan Görüşmeci-9, 2010'da yapılan görüşmede "Kadınların ekonomik özgürlü̈̆̈̈ olmasl gerekiyor, olmayınca olmuyor işte, eşim bana ne kadar bir şey söylemese de olmuyor" derken, eşinin kendisine baskı yapmamasının, kendisini özgür hissetmesine yetmediğini anlatmaktadır. Görüşmeci-9'un ifadelerinden anlaşılacağ 1 üzere, görüşmecinin üzerindeki baskı tek kaynaktan gelmemekte, eşinin baskısı olmasa da hissettiği baskılanma durumundan duyduğu rahatsızlığı yansıtan ifadelerle, kendisini eksik hissettiren durumları -örneğin ekonomik özgürlüksüzlük- anlatmakta, özerk olmadığı gerçeğini vurgulamaktadır. Bauman'ın $(2000,89)$ dile getirdiği gibi, insanlar üzerlerindeki iradeye farklı tepkiler geliştirebilirler; bu tepkiler onların özerk olmadığı gerçeğini değiştirmez. Görüşmeci-9, kendisiyle yapılan ikinci görüşmede, baskı altında büyüdüğü için kendisini sürekli baskı altında hissettiğini ifade etmiştir:

"Biz Sivas'ta yetiştiğim için bir baskı vardı. Orda böyle bir şey yapamazdım. Ama şimdi herkes ne diyor diye umursamıyorum. Hayatım değişti. Dünyaya bakış açım değişti. İçime kapanmıştım. Evdeydim. Buraya koşa koşa geldim. Ben bu tiyatroya gelirken evdeki bütün sorunlarımı unutuyorum. Gerçekten unutuyorum. Burası bana huzur veriyor, kafam dinleniyor. Ben buradan çıknca "haa benim evim var, ben eve gidiyorum, öyle mi? ” diyorum" (Görüşmeci-9, kişisel görüşme, 25.12.2015).

Görüşmeci-9'un ifadelerinden evin, içine kapandığ 1 , ev işleri ve aile sorunlarıyla baş etmek zorunda olduğu ve dilediği zaman uzaklaşamadığı bir alan olduğu çıkarsanabilir. Bauman'a göre de tuğla ve çimentoda cisimleşmiş haliyle " $e v$ ", öfke ve isyan duygularını besler. Ev dışarıya 
kapalıysa, dışarıya çıkmak uzak bir ihtimalse (...) ev zindana dönüşür:

"Zoraki hareketsizlik, bir yere bağlı birakılma hali ve başka yere gitme imkânından yoksun olmak en çekilmez, acımasız ve iğrenç durum olarak görünür gözümüze; bu durumu özellikle kinci yapan, bilfiil hissedilen hareket isteğinin hayal kirıklı̆̆lyla karşılaşmasından çok, hareketin yasaklanmasıdır. Hareket etmekten men edilmiş olmak, yetersizliğin, acizliğin -ve acının- en güçlü simgesidir" (Bauman, 2012b, 123).

Evin dışında olmak için bir nedene kavuşan Görüşmeci-9, 2015 y1lında yapılan görüşmede "burası bana özgürlügü kazandırdı" diyerek, projeden kazanımını ifade etmiştir. Sizce özgürlük nedir sorusunu ise, "kuş gibi olmak... İçimde kuşlar uçuşuyor" biçiminde yanıtlamıştır.

Katılımcı kadınlar için özgürlüğün deneyimlendiği bir alan yaratan tiyatro projesi, hayatlarında yaşadıkları kısıtlanmışlıkları da fark etmelerine neden olmuş görünmektedir. Bauman $(2016,69)$ da, özgürlük arzusunun ortaya çıkabilmesi için baskının deneyimlenmiş olmasını gerekli görmektedir. Aynı biçimde özgürlüğün deneyimlenmiş olması, baskıya ilişkin farkındalığı da açığa çıkarabilmektedir. Görüşmeci-3, tiyatroya katılmadan önce kadın olmanın "erkeklerin emri altında evde oturmak, çocuk bakmak, yemek yapmak"la görevli olmak anlamına geldiğini düşündügünü, ancak sonrasında bu düşüncesinin değiştiğini ifade etmiştir: "Önceden kadın kocasının sözünden çıkmaz bir köle gibi yaşar sanıyordum ama öyle değilmiş". Aynı görüşmeci, aynı görüşmede, çalışan kadınların da çalışmayan kadınlarla aynı sorunları yaşadığına ilişkin fikrini "bilgili kadınların da sorunları var, dayak yiyen bir öğretmen tanıdı̆̆ım var: Bir kimliği olunca kadın kadındır" biçiminde ifade etmiştir (Görüşmeci-3, kişisel görüşme: 10.05. 2011). Yine aynı görüşmeci, 2015 yılında yapılan görüşmede projenin kendisine katkılarını şu şekilde dile getirmiştir:

"Tiyatrodan önce bir şey düşünmezdim, mal gibi yaşadım. 48 yaşına kadar bir şey yaşamadım ben. Benim de var olduğumu öğrendim, bir insan olduğumu öğrendim... Özgürlük kendine öz güvendir. Benim özgüvenim tiyatrodan önce yoktu. Dünya ne kadar genişmiş... Dar yaşamışım. Insana kendi kendisine ben de bi iş becerebiliyorum ben de bu işi yapabiliyorum diye gurur duyuyorsun. Oyundan sonra tebrik ediyorlar, gururlanıyoruz. Her ev kadını eve tıkılmasın bulaşık çamaşır vs işle uğraşmasin ... biraz da sosyal işlerle uğraşsınlar".

Görüşmeci-3'e, tiyatro projesi biterse ne kaybedeceği sorulduğunda, özgüvenini yitireceğini ve kendisini kaybedeceğini belirtmiştir (Görüşmeci-3, kişisel görüşme: 25.12.2015).

2011 yılında yapılan görüşmede, Görüşmeci-4, projenin kendisine katkısını ailesinin desteğinden memnuniyetini dile getirerek ifade etmiştir:

"Başlangıçta benim artık yaşama dönmem için -projeye katılmamaolumlu baktılar, ben depresyondaydım. Ben Türkiye'deki değişimin olumlu olmadiğını düşünenlerdenim. Aileden gelen politik bir duruşum var ve ülkeye, bu durumlara karşı umudum kalmamıştı. Ama şunu ögrendim bir insan bin insan. 60 yaşından sonra bunu öğrendim. Ben bu kadar hümanist değildim ama şimdi tüm insanları kucaklamaya dinlemeye çallş̧yorum" (Görüşmeci-4, kişisel görüşme: 14.06.2011).

Aynı görüşmeci, 2015 yılında yapılan görüşmede, projenin kendisine kazandırdıklarını anlatması istendiğinde özgürlük hissine vurgu yaparak şunları dile getirmiştir: 
"Sahnede özgürüm. Özgürlük olmazsa insan olmaz ki. Hayatın içinde söyleyemediklerimi sahnede en azından satır aralarında vurguluyorum, doğru gitmeyen şeyleri vurguluyorum. En azından kendi yorumumu katıyorum, senaryo olsun, yönetmenin yorumu olsun... Yani kendin oluyorsun. Bir şeyler ifade ediyorsun, bir şeyler anlatmaya çalışıyorsun" (Görüşmeci-4, kişisel görüşme: 25.12.2015).

Görüşmeci-4, proje sona ererse ne kaybedeceği sorulduğunda, düşüncelerini yine özgürlük ve var olmak çerçevesinde dile getirmiştir:

"Bir dönem hastalı̆̆ımdan dolayı gelemedim. Yalnızlaşıyorsun. Eksiklik hissettim. Benim özgürlügüum bu. Burada olmakla var olduğunu anliyorsun, var oluyorsun. Bir şeyler üretiyorsun, bir işe yartyorsun. Burada topluma bir şey kattyorsun. Evde sadece çocuğuna, eşine kattyorsun. Bazen bir kelime bütün hayatın yönünü değiştiriyor" (Görüşmeci-4, kişisel görüşme: 25.12.2015).

Projeye iki kızı ile birlikte katılan Görüşmeci-5, 2011 yılında yapılan görüşmede tiyatro projesinin kendisini özgürleştirdiğini belirtmiştir:

“Özgürlük, baştan yaratılış. Beni yeniden doğurdu tiyatro. Özgürlüğümü verdi elime yani. Insan kendi kendisinin zinciri olur mu?, o ne der bu ne der [derdim]. Zincirlerini kirmama sebep oldu. Şimdi rahatlikla oradan buraya gelebiliyorum, tiyatroya geliyorum diye. Ama önceden ben kızları öne çıklyordum, kızlar geliyor gibi geliyordum ben. Onun için ne bileyim bana çok şey verdi. Hayatı kazandırdı. (...) Özgür bir kuş oldum yani kanatlandım yani öyle bir şey oldu, anlatılmaz yani" (Görüşmeci-5, kişisel görüşme: 14.06.2011).

Görüşmeci-5, kendisi için seçim yapma özgürlüğünden yoksunluğunu bertaraf edebilmek için kızlarının sosyal bir projeye katılımını sağlama gerekçesini öne çıkardığını ifade etmektedir. Bauman $(2014,26)$, insanoğlunun özgür olmak için yaratıldığını, seçim yapmanın zahmetlerine katlanmaktan kaçınmaya çalışsa da, "önümüzde daima gidebileceğimiz birden fazla yol olduğu" için buna zorunlu olduğumuzu söylemektedir. Bazı seçenekler diğerlerine göre daha az risklidir: örneğin toplum tarafindan kınanma olasılığını en aza indirebilir. Görüşmeci-5'in tiyatro projesine katılımını gerekçelendirirken, toplumsal olarak kınanma olasılığını bertaraf etmeye çalıştığı, yukarıdaki ifadelerinden anlaşılabilmektedir. Bauman (2012b, 19-20), kişinin aşina olmadığı alanları " $u z a k$ " olarak tanımlamakta ve güvenli ve tanıdık alanların sağladığı kolaylıkların, uzak alanlardaki yokluğundan bahsetmektedir. Bu durumda uzaklık, sadece coğrafi mesafe olarak değil, bir yaşam biçimine uzaklık olarak da anlaşılmalıdır. Görüşmeci-5' in ifadelerinden de anlaşılacağı üzere, aşina olunan alanlardaki güvenlik ve kabul duygusu, aslında kendisini zincirlenmiş hissettiği bir başka duygu durumunun kaynağıdır. Bilmediği alanlara yeni bir faaliyet alanına- doğru yönelmesi, yeni bir hareket alanına kavuşması Görüşmeci-5 tarafindan özgürlük olarak betimlenmektedir.

Aynı görüşmeci, 2015 yılında yapılan görüşmede, birinci görüşmede verdiği yanıtlara benzer yanıtlar vermiştir. Projenin kendisine kazandırdıkları konusunda yine özgürlük odaklı söylemlerde bulunmuştur: "Hayatımı, gençliğimi, özgürlü̆̆̈̈mü [kazandırd1]. Beni başka biri yaptı. Hayata bakış açımı değiştirdi. Provalara geldikçe sahneye çıktıkça insanlara karşı önyargımı aştım. Insanlara yaklaştıkça insanları tanıdım. Kendime koyduğum yasakları tanıdım" (Görüşmeci-5, kişisel görüşme: 25.12.2015). Görüşmeci-5, özgürlüğü nasıl tanımladığı soruldu- 
ğunda “Özgürlük kendini ifade edebilmek. Prangalarımdan kurtuldum. Özgürlük bu hayat baklş açısı" şeklinde yanıtlamıştır (Görüşmeci-5, kişisel görüşme: 25.12.2015).

Görüşmeci-6, "çocuk gelindim ben" diyerek başladığı konuşmasında 13 yaşında kaçırılarak evlendirildiği anlatmıştır. 2011 yılında yapılan görüşmede, proje aracılığı ile kazandıklarını " $B u$ projeden insan olduğumu ögrendim, insanlara sevgiyle bakmayı ögrendim, kalp krizi geçirirken, ben yoldan döndüm, yani tiyatro beni yaşama döndürdü. (...) Tiyatro şimdi benim için aşk demek, yani kendini ifade edebilmek demek, anlatılmaz, yaşanır" şeklinde ifade etmiştir (Görüşmeci-6, kişisel görüşme: 10.05.2011). Okuma yazmayı sonradan öğrendiğini söyleyen Görüşmeci-6, eskiden duygularını gizlediğini, insanların gözlerine bakamadığını bu görüşmede belirtmiş, projeye sonrasında ise sevindiğini, üzüldügüunü ifade edebildiğini dile getirmiştir. Kendisine ilişkin özfarkındalığındaki artışı, kendini ifade etme becerisindeki gelişmeyle özdeşleştiren Görüşmeci-6'nın ifadeleri, Bauman'ın $(2016,54)$ öz farkındalığa ilişkin görüşleri ile örtüşmektedir. Bauman'a göre, “Özel, daha doğrusu yüce, değer damgası, bir kere kişinin başka türlüsü sıradan olacak yaptıkların yapma ve düşündüklerini düşünme deneyimine iz bıraktığında, bunu şiddetli bir öz farkındalık, yani kişinin 'kendine' hassas ilgi ve görgü nesnesi olarak bakması için bir dürtü, takip eder". Bu durum, kadınlarla yapılan görüşmelerdeki ifadelerde "benlik" vurgusuyla sık karşılaşılma durumunu açıklar niteliktedir. Kadınların benlik farkındalığı yaşadığına ve tiyatronun bunu nasıl sağladığı ilişkin ifadelere 2015 yılında yapılan görüşmelerde rastlanmıştır:

"[Tiyatro] bana kendimi, ... [Görüşmeci-6 ismini söylüyor] olduğumu ögretti. Kendimi çok seviyorum, bambaşka bir insan oldum. Hemen yatsam uyusam, ölsem dediğim günlerim oldu. Ama tiyatro beni hayata bağladı. Yani insanları o kadar seviyorum, yolda yürürken insanların gözlerine bakıyorum. Eskiden gözlere değil de yere bakıyordum. (...) Evde bazen böyle perişan oluyorum. Şekerim var, tansiyonum.... Girdiğim zaman salonumuza, sahneye çıkınca provada, ben [Görüşmeci6 ismini söylüyor]...'e dönüyorum ama o evdeki pasif ... [Görüşmeci-6 ismini söylüyor] değil de böyle içimdeki yapamadıklarımı yapan, bambaşka oluyorum. Harika şeyler düşünüyorum, yaşıyorum. Kendimi gerçekten çok seviyorum" (Görüşmeci-6, kişisel görüşme: 25.12.2015).

Goldman'a göre özgürlük aşkı evrenseldir ve hiçbir tiranlık şimdiye kadar onu ortadan kaldırmaya muvaffak olamamışır. "Özgürlük ve kendini ifade etmeye duyulan şiddetli arzu, insanda temel ve baskin bir niteliktir" (Goldman 2006, 132). Görüşmeci-6'ya özgürlüğün kendisi için ne anlama geldiği sorulduğunda, tiyatronun özgürlük, özgürlüğün de kendini ifade edebilmek demek olduğu yanıtı alınmıştır: "Yani diyemediklerini sahnede diyebiliyorsun, söyleyebiliyorsun. Yani Özgürlük budur bence, kanatlanıp uçuyorsun hocam, başka ne diyeyim ki o kadar güzel, yaşamak lazım" (Görüşmeci-6, kişisel görüşme: 25.12.2015). Bu proje biterse "Daha içine kapanık olurum. Dilerim bu projeyi sonuna kadar götürürüz. Iyi ki bu projenin içindeyim. Ben [Görüşmeci-6 ismini söylüyor] olduğumu daha yeni anladım" diyerek, proje sonlanırsa kaybedeceğini düşündüğü şeyin, benlik duygusu olduğunu dile getirmiştir.

Görüşmeci-7, 2011'de yapılan görüşmede, ne kadar araştırsa, okusa, düşünse de söylemek istediklerini bir türlü istediği gibi ifade edemediğini dile getirmiş, tiyatroya katılma nedenini, "Ben düşündüğümü özgür olarak söylemek istiyorum. Kendimi aşmak, özgür olmak için geldim aslında. Hocamız bir kellime söyler misin dedi ve ben güldüm. Ístediğim gibi söyleyemedim, içimde bastırıyordum bazı duyguları. Neden ben kendimi bastırıyorum? Çalışmış bile olsam susmuşuz aslında hep, hiç özgür olamamışız. Ben uçmak istiyorum, özgür olmak istiyorum" 
(Görüşmeci-7, kişisel görüşme, 10.05.2011) cümleleriyle belirtmiştir. Tiyatronun ilk zamanlarında kelimeleri olması gerektiği gibi söyleyememesinin nedeni olarak, baskı altında tuttuğu duygularına işaret etmiştir. Bu ifadeler karşılığını Bauman'ın vurgularında bulmaktadır: insanların gönüllerinin istediği şeylerin peşine kolayca düşmelerini engelleyen baskılar ve kısıtlamalar, uygarlığın insanları korkudan kurtarmasının bedelidir ve bu bedeller bireysel özgürlükler alanında büyük daralmalarla ödenir:

"İçgüdülerin sinırlar içinde tutulmasına ya da tamamen bastırılmasına neden olan bu kisitlamalar "ruhsal rahatsizlıklara, nevrozlara ve isyana gebe mutsuz edici bir durumdur. Freud'a göre en yaygin huzursuzluklar ve düzeni tehdit eden davranış tipleri, bireysel güvenlik adına hep birlikte ve ayrı ayrı kazandı̆̆ımız şeyler karşılığında bireysel özgürlüğ̈̈n çok fazla feda edilmesinden kaynaklanmaktadır" (Bauman 2000, 24-25).

Görüşmeci-7, 2015 yılında yapılan görüşmede projenin kendisine ne kazandırdığı sorusunu " $B u$ proje beni kanatlandırdı. Konuşmak anlatmak istediklerimi söyleyemediğim duygularımı bastırdiğım anlarım vardl. Yani farkinda olmadan... Oyun oynadık. Bana rol verildi onu oynadım. Çok ilginçlikler yaşadım. Bu proje hayata bağllyor, tutunmasını sağllyor. Tek kelimeyle diyebilirim ki dilsizi dillendiriyor" (Görüşmeci-7, kişisel görüşme, 25.12.2015) şeklinde yanıtlamıştır. Özgürlük nedir sorusuna verdiği yanıtta ise "İnsanın düşündüğünü hayata geçirebilmesidir. Bizim yapmak istediklerimizi hayata geçirmektir, biz özgür gibi görünsek de engelleniyoruz. Burda kendimi özgür hissediyorum" (Görüşmeci-7, kişisel görüşme, 25.12.2015) ifadeleri yer almaktadır.

Bauman $(2000,89)$, özgürlüksüzlüğü, insanın başka birinin kural ve emirlerini izlediği durum (...) yani eylemde bulunan kişinin başka birinin iradesinin taşıyıcısı olduğu bir durum, olarak açıklamaktadır. Aile içi iş bölümü, pek çok kadının sorgulayamayacağı dışsal bir irade tarafından belirlenmiş davranış örüntülerini inşa eder. Bu örüntülerin dayattı̆̆ı, erkeğe tabiiyet durumu, kadının hareket özgürlüğünü de kısıtlamaktadır. Görüşmeci-8, 2011 yılında yapılan görüşmede eşinin izni olmadan çarşıya bile gidemediği zamanlardan söz etmiş, şimdi tiyatro projesine gelebildiği için arkadaşlarının ona imrendiğini belirtmiştir. Projenin kendisine ne kazandırdığı sorusuna "Dünyaya küsmüştüm. Şimdi daha sevecen baklyorum, bir şeyler yapmak projeler üretmek istiyorum. Bir şeyler yapmak benim kişiliğimi kazandırıyor. (...) Yani farklı bir kişi oldum daha doğrusu. Tiyatro oynuyorum. Sanki kanatlanmış gibiyim" yanıtını vermiştir (Görüşmeci-8, kişisel görüşme: 10.05.2011). Görüşmeci-8'in, tiyatro projesine katılma yönünde yaptığı seçimden duyduğu memnuniyeti anlatırken kullandığı ifadeleri, Bauman'ın seçimlerimizi şekillendiren iki etken olarak bahsettiği "yaşam şeklimiz" ve "hayatımızın yörüngesi" kavramsallaştırmaları üzerinden değerlendirmek mümkündür. Görüşmeci-8'in "bir şeyler yapmak bana kişiliğimi kazandırıyor" cümlesiyle ifade ettiği durum, kadının kendi yaşam biçimini kader olarak görmekten vaz geçip, karakterini geliştirici etkisinin peşine düşerek katıldığı tiyatro projesinde vücut bulmaktadır. Görüşmeci-8, eşinin karşı çıkmasına rağmen tiyatro projesine devam etmeyi seçtiği -alan gözlemlerinden- bilinmektedir. Görüşmeci-8' in "kişiliğini kazanma" durumuna yaptığı vurgu, Bauman'ın koşullar ve eylemlilik hali arasındaki ilişkinin seçimlerimizi şekillendirici etkisi üzerine söyledikleriyle çakışmaktadır:

Kendi aralarında seçimlerimizi şekillendiren, birbirinden büyük ölçüde bağımsız iki etken vardır: yaşam şeklimiz ve hayatımızın yörüngesi. Bunlardan biri, üzerinde hiçbir etkiye sahip olmadığımız koşullar dizisi olan "kader': diğer bir deyişle, (doğduğumuz coğrafi ve sosyal konum veya doğum tarihimiz gibi) biz yapmadı̆̆ımız halde" başımıza gelenlerdir. Diğer etken ise, üzerinde (en azından prensipte) belli bir etkiye sahip olduğumuz, işleyebileceğimiz, 
eğitebileceğimiz ve geliştirebileceğimiz karakterimizdir. "Kader', gerçekçi seçeneklerimizin listesini belirler, fakat bunların arasından nihai seçimi yapan karakterimizdir" (Bauman 2014, 26) .

Aynı görüşmeci 2015 yılında yapılan görüşmede de benlik, kişilik ve özgüven ve kendini ifade etme temelinde yanıtlar vermiştir. Projenin kendisine ne kazandırdığ 1 sorusunu "Bana özgüven kazandırdı. Yani farklı bir kişi oldum daha doğrusu. Daha rahatım, herkesin içinde kendimi ifade edebiliyorum. Her yerde farklı bir kişi oldum, yazl şiir yazıyorum. Müzik söylüyorum. Tiyatro oynuyorum. Sanki kanatlanmış gibiyim" şeklinde yanıtlamıştır. Özgüvenin kendisi için anlamını "anlatamadığın herhangi bir şeyi anlatmak yani, içindekini çıkarmak, diline çıkarmak, içinde bırakmamak, rahat bir şekilde konuşmak" olarak belirtmiş ve "Ben bunu yapabilirim" diyerek kendine güvenini ifade etmiştir (Görüşmeci-8, kişisel görüşme: 25.12. 2015). Aynı görüşmeci özgürlüğün kendisi için ne anlama geldiği sorulduğunda, özgüven ve kendini ifade etmek kapsamında yanıtlar vermiştir:

“Özgürlük, basklnın olmadĭ̆g bir şeydir. Kendi kendine daha rahat konuşabilmek, gezmek... nasıl desem özgürlük farklı bir şey özgürlük... burda özgürlük çok, evde de özgüvenim gelişsiği için daha özgür hissediyorum doğrusu. Çünkü daha önceleri kendimi ifade edemediğim için özgür değildim. Ama şimdi kendimi özgür hissediyorum, daha farkllyım. Yani param olmasa, pulum olmasa da kendimi özgür hissediyorum, kanatlanıyorum" (Görüşmeci-8, kişisel görüşme: 25.12.2015).

Görüşmeci-10, kadınların en büyük sorunu olarak nitelendirdiği 'baskı altında yaşamak'tan duyduğu rahatsızlığ 2011 yılında yapılan görüşmede dile getirmiştir. Aynı yıl yapılan görüşmede, projenin kendisine katkısını "En önemlisi özgüvenimi kazandım. Hayır demesi gereken şeylere hayır demeyi ögrendim. Çocuklarıma hayır denilmesi gerektiğinde hayır demeyi ögrendim. Önceden nasıl konuşacă̆ımı bilemezdim. Şimdi her şeyimi bu projeyle ortaya çıkardım. Kendime gelmişim yani, sanki ben senelerce oynamışımda burada kendime gelip özgürlügüme kavuşmuşum dedim" (Görüşmeci-10, kişisel görüşme, 10.05.2011) biçiminde ifade etmiştir. 2015 yılında yapılan derinlemesine görüşmede sahnede yaşadığı hisleri, kanat metaforuyla anlatmıştır:

"Ben sahneye çıktı̆̆m zaman, sanki sahnenin tozunu yutmuşum da, senelerdir o sahnede kalmışım da oyuncu olmuşum gibi hissediyorum kendimi. Özgüvenim geliyor. Ama evdeyken, sanki hiçbir işe yaramamış, atılmış, ne bileyim kendimin hiçbir şey olmayışı, özgüveni olmayan bir kişi gibi görüyorum kendimi. Ama buraya gelip de projenin içine girdiğim zaman uçuyorum, havalara uçuyorum. Kanatlanıp uçuyorum. Eskiden tiyatroya hiç gitmedim ben. Tiyatro bilmiyorduk ama tiyatroya başladık, özgüven de ondan sonra geldi" (Görüşmeci-10, kişisel görüşme: 25.12.2015).

Görüşmeci-10 özgürlüğün karşıllğ1 olarak özgüveni konumlandırmaktadır: "Bence özgürlük, özgüvenin geldi mi hiçbir şeyi gözün görmüyor. Demek ki ben önceden özgür olamıyormuşum. Oğlumdan tiyatroya gelirken saklamıştım. Neden? Çünkü özgür değilmişim demek ki. Ben bu projenin içine girince özgürlüğ̈̈n ne olduğunu anladım. Özgürlük demek, alıp başını gitmek değil, özgüvenini kazanmak demek bence" (Görüşmeci-10, kişisel görüşme: 25.12.2015). Bauman'1n $(2014,26)$ riskli seçenekler olarak belirttiği ve onaylanmamayı beraberinde getirdiği -daha önce Görüşmeci-5' in ifadelerinde rastladığımız- seçenekler, Görüşmeci-10 tarafından da başlangıçta, tiyatro projesine katılımını oğlundan gizleyerek, bertaraf edilmeye çalışılmıştır. 
Bauman (2016, 18), “özgür olmak bir kurumun, bir şehrin veya bir mülkün ayricalıklı haklarına sahip olmakla eşdeğer görülür" demektedir. Görüşmeci-11, evli, 55 yaşında bir ev kadınıdır, ancak kendisini amatör tiyatrocu olarak tanımlamakta ve bundan büyük mutluluk duyduğunu ifade etmektedir. 2011 yılında yapılan görüşmedeki ifadelerinden, bir şehrin ya da konumun ayrıcalıklı haklarına sahip olduğunu hissettiği anlaşılmaktadır: "Bi doktora gittim, doktora tiyatro yaptığımı ve turneye çıkacağımızı söyledim ve bana daha önce randevu verir misiniz dedim. 'Tabi ki veririz sanata saygımız var' dedi. O kadar mutlu oldum ki uçtum sanki kanatlanarak. $O$ anki hissettiğimi anlatamam. Orda bile bana faydası oldu yani, sosyallik çok güzel bir şey. Ben ev hanımı olmayı kendime yakıştıramıyordum, tiyatro mutluluğu getirdi hayatıma" (Görüşmeci-11, kişisel görüşme: 14.06.2011). Bauman (2016, 18), özgürlük teriminin on altıncı yüzyılın sonlarına doğru soyluluk, cömertlik, asillik gibi güç timsali olan kavramlarla eş anlamlı olarak kullanıldığını, daha sonra terimin kavramsal içeriği soyluluk bağlantısını kaybetmiş olsa da ayrıcalıkla bağının devam ettiğini belirtmektedir.

Görüşmeci-11, ev kadını olmayı hiçbir zaman sevmediğini, kendisinde keşfedebileceği şeyler olduğunun farkında olduğu ve tiyatro projesinin kendisine katkılarını görüşme esnasında ifade etmiştir: "Sarhoş oluyorum tiyatroda. O kadar mutlu oluyorum. Sahne tozu dedikleri doğruymuş, hayat bize böyle bir güzellik yaptı. Tek kaygım proje biterse sahneye çıkamazsam ne yaparım korkusu oluyor" (Görüşmeci-11, kişisel görüşme: 14.06.2011).

Görüşmeci-11, 2015 yılında yapılan derinlemesine görüşmede, özgürlük ve tiyatro arasında kurduğu bağı anlatmış ve en çok sahnede alkışlandığında özgürlüğü hissettiğini belirtmiştir: " $O$ alklşlarla, orda zaten çok özgür oluyoruz. Özgürlük uçmak yani, yaşamak... Özgürlükle tiyatroyu bağdaştırıyorum, çünkü bundan önce biz evde oturuyorduk. Ev kadınıydık” (Görüşmeci11, kişisel görüşme: 25.12.2015). Bauman (2016, 17-18) özgürlüğün birbirinden kesin biçimde ayrılmış iki sosyal durumun birlikte var olmasını temsil ettiğini söylemektedir. Özgürlüğe ulaşmak ve özgür olmak ise kavramsal olarak "düşük sosyal durumdan daha yükseğe çıkmak anlamına gelir. Bu iki sosyal durum pek çok yanıyla birbirinden ayrılır fakat karşıtlıklarının içinde özgürlüğ̈̈n niteliğiyle ilgili bir yönü daha fazla sivrilmiştir. Bu, başkalarının iradesine bağlı eylem arasındaki farklılıktır". Görüşmeci-11 için ev kadınlığı "insanın hayatında başına gelebilecek en kötü şey. Ev kadını olmak kendini pek geliştirememek... Ev kadını olmaktan nefret ediyordum ben. Şimdi amatör tiyatrocuyum ben desem, bir ortamda konuşma şansın oluyor. Çünkü ben hiç çalışmadım, eşim çok kıskançtı, beni çalıştırmadı. Klyafetlerimi yırtardı eskiden kıskançlığından" derken, düşük sosyal statüden yüksek sosyal statüye geçtiğini ifade etmektedir. Bauman'a (2016, 98-99) göre de "kişinin yaşamının değerliliğine ve saygınlı̆̆ına değer biçen, iş ve işe yönelik olumlu tavrın çeşitli çehreleriyle (endüstri, çalışkanlık, uygulama, girişim gibi) bağlantıl kriterlerdir. (...) Insanlar kendilerini mesleki becerileri ve uygulama yeteneğini kazandıkları iş türü açısından tanımlarlar".

Görüşmeci-12, hayatının evin içinde geçtiğini, projeye de "en azından evden çıkabilirim" umuduyla katıldığını belirtiyor. Görüşmeci-12 için ev, Bauman'ın deyişiyle "zindan"a dönüşmüş: bu durumu "herhalde evde otursaydım kafay yerdim, çürüycekmişim gibi hissettim" (Görüşmeci-12, kişisel görüşme: 25.12.2011) şeklinde ifade etmiştir. Ev, Görüşmeci-12 için, sürekli aynı işlerin yapıldığı, yabancılaştırıcı ve kısıtlanmış bir hayat biçiminin simgesidir. 2011 yılında yapılan derinlemesine görüşmede daha farklı, daha özgür hissettiğini, kendisini daha iyi ifade edebildiğini şu şekilde anlatmıştır:

"Insanlara rahatça yaklaşamazdım, şimdi daha rahat girip çıkabiliyorum. Buna girmemiş olsan sizinle rahat olamazdım. Doktora gitsem bile rahat olamıyordum. Önceden sürekli ev işi yapardım, şimdi her zaman 
ev işi yapmiyorum. (...) Erkeğin kölesi yani kadınlar. Özgür olamazsan erkeğin kölesi olursun. Önceden böyle düşünüyordum ama şimdi böyle olmadiğı düşünüyorum. Meğer kadınlar erkeklerin kölesi değilmiş. Bu düşünce aileden gelen bir şeydir. Sen bu adamla evlendin bu adamin kölesisin diye düşündürülüyor. Önceden daha fazla evde vaktim geçiyordu, şimdi provalar sayesinde çok fazla evde geçmiyor zamanım. Evde televizyon izlemek gibi boş vaktim olmadl. Kendimi dışarı atasım gibi geliyor projeden sonra. Şimdi daha farklıyım" (Görüşmeci-12, kişisel görüşme: 25.12.2011).

Bauman (2016, 17-18), “özgürlüğ̈̈ cazip hale getiren farklıllktır" demektedir: "Onun varlı̆̆ veya yoluğu; yüksek ile düşük, iyi ile kötü, istenen ile aykırı olan arasındaki zıtlı̆̆ı açığa çıkarır ve temellendirir". Görüşmeci-12, 2015 yılında yapılan görüşmede "Proje beni öne çıkardı" derken, kendi benliğine vurgu yapmaktadır. Bauman'ın $(2016,60)$ George Simmel'e referansla dile getirdiği, "benzersizlikte ve özellikte son nokta"yı aramaya yönelik bireysel yatkınlı, "gitgide" kıyaslanamaz "içerikler ve sunulardan oluşan" hayatın bir gerekliliği olarak konumlandırılır. Benlik, bu noktada katılımcı kadınlar için, kişisel farklılıklarının, benzersizliklerinin

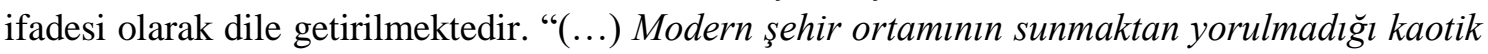
etkiler kasırgası içinde kişinin umut edebileceği tek sağlam zemin (ki bu bile boşunadır) kendi 'kişisel kimliği'dir' (Bauman 2016, 60). Goldman da Henrik Ibsen'in özgürlük mücadelesini konu alan saptamasından yola çıkarak, özgürlük mücadelesini, sadece özgürlüğe ulaşmakla sınırlı olmayan, insan karakterinin en güçlü en kararlı kurtuluş mücadelesi olarak nitelendirmektedir (Goldman 2006, 7).

Görüşmeci-12, 2015 yılında yapılan görüşmede projenin kendisine kazandırdığı şeyleri ifade ederken özgürlüğe vurgu yapmış, sahnede özgür olduğunu dile getirmiştir: "orada istediğimizi yapabiliyoruz". Görüşmeci-12, özgürlük sizce nedir sorusunu, "bu proje zaten özgürlük, projenin kendisi özgürlük. (...) Üstünde bir baskı olmazsa özgürsündür. Birisi seni bir şeyler yapmak zorunda tutmazsa sen özgürsündür yani. Birisi sana sürekli bir şeyler yap diye baskı uygularsa özgürlük yok" şeklinde yanıtlamıştır (Görüşmeci-12, kişisel görüşme: 25.12.2015). Bu ifadeler, Bauman'ın baskıya ilişkin dile getirdikleriyle örtüşmektedir. Bauman $(2016,12)$ sınıf, güç, egemenlik, otorite, toplumsallaşma, ideoloji, kültür, eğitim gibi kavramların, insanın sosyolojik haritasını düzenlediğinden bahsetmektedir. Bütün bu kavramların ortaklaştığı nokta olarak da baskıya işaret eder: "kişisel iradeye sinırlar koyan ya da gerçekleşen eyleme (tasarlanmış eylemden farklı olarak) müdahale eden bir dış baskı düşüncesi”ne.

Görüşmeci-13 ile 2015 yılında yapılan görüşmede alınan yanıtlar da yine özgüven ve özgürlük çerçevesindedir. Projenin kendisine kazandırdıklarını ifade etmesi istendiğinde " $\ddot{\text { zggü- }}$ venimi kazandırdı. Sosyal ilişkilerimi artırdı. Sahneye ilk çıtı̆̆ğmda hiçbir şey yapamadığımı gördüm. Bir süre sonra yapamam dediğim bi çok şeyi yaptı̆̆ımı gördüm. Hatta türkü söylemeye bile cesaret ettim" (Görüşmeci-13, kişisel görüşme: 25.12.2015) cümleleriyle kazanımlarını dile getirmiştir. Görüşmeci-13'ün, "Kendimi özgür hissetmek için çaba sarf ediyorum ama örf adetler, çevre... Burada özgürüm, evde asla söyleyemeyeceğim şeyleri sahnede rahatlkla söylüyorum. Evde ağzımdan çıkmaz ama sahnede söyleyebiliyorum. Hiç kimsenin hakkına tecavüz etmeden her konuda özgür olmayı isterim" biçimindeki ifadelerinde, özgürlüğ̈̈, kendini ifade etmek ve özgüven çerçevesinde tanımladığı görülmektedir. Proje sona ererse ne kaybetmiş olacağı sorusuna verdiği yanıtlar da bu ifadeleri desteklemektedir: "Özgürlü̆̈̈̈mü, özgüvenimi kaybederim. Duygu düşüncelerimi burada arkadaşlarımla paylaştığımda yanlı̧̧ düşüncelerimi geri çekiyorum, doğru düşüncelerim bana güven veriyor. Ben bunları ögrenmişim diyorum, 
bunlar bana güven veriyor. Bunlar gider... Özgürlügü̈m gider" (Görüşmeci-13, kişisel görüşme: 25.12.2015).

Bauman (2013, 22), "eğer demokratik haklar ve onlara eşlik eden özgürlükler, teoride mevcut ancak pratikte sağlanamıyorlarsa, çaresizliğin acısının üstüne bir de bahtsızlı̆̆ın utancı eklenecektir" demektedir; "çünkü sonuçta hayatın her gün sunduğu zorluklarla mücadele edebilme yetisi, ya bireylerin özgüvenlerinin ve haysiyetlerinin beslenmesini sağlar, ya da onları yerle bir eder". Kadınlar için tiyatro projesi, hayatlarının tamamında özgürlük sağlamasa da kamusal alanda özgürlük deneyimi elde etmelerini ve kadın mücadelesine aktif katılımlarını sağlamıştır. Bu katılımın, katılımeı kadınlara özgüven sağladığına ilişkin pek çok ifade, katılımcı kadınlarla 2011 ve 2015 yıllarında yapılan derinlemesine görüşmelerde yer almaktadır. Görüşmelerin analizleri sonucunda, kadınların tiyatroya katılmadan önceki zamanı, katıldıktan sonraki zamandan, özgüven, kendini ifade etme ve özgürlük algıları açısından farklı değerlendikleri görülmüştür.

\section{Sonuc}

Kadınlar Tiyatroyla Buluşuyor projesinde, katılımcı kadınlarla yapılan görüşmelerde, katılımcı kadınların "özgürlük" kavramının içini genellikle "kendini ifade etme" durumu ile doldurdukları görülmektedir. Bu noktada "özgürlük" ve "kendini ifade etme" arasındaki köprü kavram olarak "özgüven"i vurguladıkları; "özgüven”i ise "benlik/kişilik" kavramları üzerinden betimledikleri ifadelerle sıklıkla karşılaşılmıştır.

Üretimin gerçekleştiği zaman diliminin organizasyonunda da ataerkillik ve kapitalizm tarafından biçimlendirilmiş ilişki biçimlerinin izlerini görmek mümkündür. $\mathrm{Bu}$ izler takip edildiğinde, ev içinde sürdürülen işlerin toplumsal cinsiyet rollerini belirleyen normlar tarafından kadının hanesine yazılmış olmasının, kadın için serbest zamanın da çoğunlukla ev içi mekânda geçmesine neden olduğu görülmektedir. Derinlemesine görüşme sırasında kadınların "kanat" metaforuna sıklıkla başvurması, özgürlüğü evin dört duvarının dışı olarak algıladıklarını da ortaya koymaktadır. Kadınların sahneyi bir varoluş alanı olarak değerlendirdikleri yapılan analizlerle ortaya çıkarılmıştır. Sahnenin, kadınlara birer özne olarak var olma alanı sağladığı, kadınların ifadelerinden anlaşılmaktadır.

Aile içindeki baskıları, özgürlük yitimi olarak görmeye başladıklarını ifade eden kadınlar, bu tahakkümün normal olmadığını da projede yaşadıkları özgürlük deneyimleri sayesinde fark ettiklerini dile getirmişlerdir. Bauman'ın da ifade ettiği gibi, özgürlük ancak baskının deneyimlenmesi sonucunda arzulanır ve özgürlük deneyimi ise daha önce yaşananın bask1/tutsaklık olduğunu belirginleştirir. Tiyatro projesi, katılımcı kadınlara bir özgürlük alanı sunmuş; özgürlük algılarını, kendini ifade etme çerçevesinde oluşan özgüven duygusu ile ilişkilendirmeleri için bir araç olmuştur. Kadınların yaşadıklarını ifade ettikleri bu özgürlük deneyimi, içinde yaşadıkları dezavantajlı toplumsal koşullara rağmen gerçekleşmiştir. Bauman'a $(2016,49)$ göre, toplumun bireylere sağlayabildiği özgürlük, ancak tehdit olarak algılanmayan koşullar altında kişilere bağışlanır ve sıkı kontrol edilen bir şeydir: “(...) böylesi bir özgürlük her zaman parçall, yani 'belirli koşullarda'dır; ya açıkça tanımlanmış, belirli yükümlülük veya yetki alanlarından muafiyete ya da bir ayrıcalığı paylaşan bir bütünlügün üyeliğine dayanır. Özgürlük esasında bir ayrıcallktır: tutumlu ve genellikle isteksizce teklif edilen bir ayrıcalı". Kadınlar tiyatroyla buluşuyor projesi, topluluk düzleminde özgürlük alanı sunan bir katılımcı sanat projesidir. Sunmuş olduğu özgürlük alanı da yine topluluk etkinliği çerçevesindedir.

Elbette toplumsal değişimde sanatın tek başına etken olabilmesi ve toplumsal değişimdeki etki derecesinin belirlenmesi ve bu değişimin göstergelerinin hemen ortaya çıkmasının beklen- 
memelidir. Ancak sanatın, kadınların özgürleşmesi için yürütülen mücadeleler için destekleyici bir alan olarak değerlendirilmesinin önünde de her hangi bir engel yoktur. Bunun için katıllimcı sanatın, kadın mücadelesinde farkındalığı yükseltici bir aktivizm biçimi olarak güçlendirilmesi, yaygınlaştırılması gerekmektedir.

Tüm toplumsal ilişkilerde, kadına yönelik cinsiyetçi tutumun izlerini sürme çabası, aynı zamanda cinsiyete dayalı rollerin kadını kısıtlayıcı, hapsedici etkilerini gözler önüne serme çabasıdır. Bu çabaların aktivizm boyutunun ihmal edilmemesi, kadın sorunlarıyla doğrudan ve sıklıkla yüz yüze kalan kadınların, eylem sürecine katılacakları, işe vuruk alanlarda yer almalarını sağlayacak girişimler, gerek özgürlük deneyimi gerekse farkındalık yükseltme açsısından oldukça önemlidir. Aynı zamanda umut vaat edicidir.

Katılımcı sanat projelerinin Türkiye'de genelde sanat, özelde tiyatro sanatı alanında örneklerinin artması ve kadın katılımcılığının teşvik edilmesi, her şeyden önce kadınların "özgürlüksüzlükleri” ile yüzleşmelerini, onlara doğalmış gibi gelen tahakkümün farkına varmalarını sağlayabilecektir. Yamaner'e $(2011,708)$ göre de bu tür çalışmalar umut vericidir: Türkiye tiyatrosunda kemikleşen cinsiyetçi imgelemi, kadın bakış açısıyla çözmeye çalışan genç kuşaklar, yeni dramaturjik çalışmalarda, metinle ilgili birçok akademik ve sanatsal çalışmada sesini çıkarmaya başlamıştır: "Kadın karakteri bir nesne konumunda tutan cinsiyetçi imgeleme karşı bir farkındalık ve dahası bir sorgulama var artık. Şimdilik küçük gruplar halinde. Ama yakın gelecekte kurumsal ve tutucu tiyatro yapılarına da sirayet edeceğine dair umut var. Bu, on yıllık bir çaba. Bundan bir on yıl sonrası için daha çok umut var". Kadınlar Tiyatroyla Buluşuyor projesi katılımcıları, Yamaner'in sözünü ettiği küçük gruplara örnek olarak gösterilebilir. Kadın mücadelesinin tabana yayılmasında, bu tür küçük girişimlerin de payı olacağı akılda tutulmalıdır. Goldman'ın $(2006,87)$ dediği gibi, kadının iç dünyasındaki yenilenme, gelenekle, örf ve adetlerle pekiştirilen eski önyargıların ağırlığından sıyrılmaya başlamasıyla olanaklı olacaktır. "Oy hakkl, eşit sosyal haklar çok güzel talepler olabilir, ancak esas özgürleşme, ne oy sandıklarında ne de mahkemelerdedir. Özgürleşme, kadının ruhunda başlar".

"Kadınlar Tiyatroyla Buluşuyor" projesi örneğinden yola çıkılarak, tiyatro sahnesinin kadınların sorunlarını birinci ağızdan aktarabilecekleri bir platform olarak değerlendirilebileceğine ve toplumsal rollerini dışarıda bırakıp benlik meselesi çerçevesinde yeni bir özgürlük alanı sunduğuna ilişkin bulgular doğrultusunda, kadınların özgürlük mücadelesine katkı sunacak bir yol önerisi olarak katılımcı sanatın daha yaygın biçimde çalışmalara dâhil edilmesi önemli bir adım olacaktır.

Yazarın Notu: Bu çalışma, 19-21 Mayıs 2017 tarihleri arasında Kuşadası'nda gerçekleştirilen I. Uluslararası Zygmunt Bauman Sempozyumu'nda sunulan "Kadın Mücadelesinde Katılımcı Kadınların Özgürlük Algısının Bauman’ın Özgürlük Yaklaşımı Çerçevesinde Değerlendirilmesi: 'Kadınlar Tiyatroyla Buluşuyor' Projesi Örneğinde" başlıklı bildirinin gözden geçirilmiş ve genişletilmiş şeklidir. 


\section{KAYNAKÇA}

Bauman Z. $\left(2000^{1}\right)$. Siyaset Arayıı̧ı. İstanbul 2000.

Bauman Z. (2012a). Akışkan Aşk - İnsan İlişkilerinin Kırılganlı̆̆ına Dair. İstanbul 2012.

Bauman Z. (2012b). Küreselleşme, Toplumsal Sonuçları. İstanbul 2012.

Bauman Z. (2013). Modernite, Kapitalizm, Sosyalizm Küresel Çağda Sosyal Eşitsizlik. İstanbul 2013.

Bauman Z. (2014). Azınlığın Zenginliği Hepimizin Çıkarına mıdır?. İstanbul 2014.

Bauman Z. (2016²). Özgürlük. İstanbul 2016.

Bauman Z. $\left(2017^{14}\right)$. Sosyolojik Düşünmek. İstanbul 2017.

Bora A. (2004). “Kamusal Alan Sahiden ‘Kamusal mı?”. Der. M. Özbek, Kamusal Alan (2004) 529-538. İstanbul.

Bora A. (2011). Feminizm Kendi Arasinda. Ankara 2011.

Everts S. (1998). Gender and Technology: Empowering Women, Engendering Development. London 1998.

Goldman E. (2006). Dans Edemeyeceksem Bu Benim Devrimim Değildir. İstanbul 2006.

Hacking S., Secker J., Kent L., Shenton J. \& Spandler H. (2016). "Mental Health and Arts Participation: the State of the Art in England". The Journal of The Royal Society for the Promotion of Health JRSH (2016). Doi: 10.1177/1466424006064301

Kanwar A. S. (1999). "Women Technology and Distance Education". $13^{\text {th }}$ Annual Conference Asian Association of Open Universities, Open and Distance Education Systems and Models Facing 21st Century's Information and Learning Societies, Conferance Proceedings. Volume 2. HKSAR, ChinaUSA 1999.

Kelly M. (2014). Encyclopedia of Aesthetics. Oxford 2014.

Matarasso F. (1997). Use or Ornament? The Social Impact of Participation in the Arts Comedia. Stroud 1997.

Punch K. F. (2014). Sosyal Araştırmalara Giriş - Nicel ve Nitel Yaklaşımlar. Ankara 2014.

Taşkaya M. (2013). “As Public Relationship Application Countinability of Participated Art Projects via Distance Education Method: A Case of 'Women's are Meeting with Literature Project". Turkish Online Journal of Distance Education-TOJDE (2013) 351-373.

Yamaner G. (2011 $\left.{ }^{1}\right)$. "Cumhuriyet Dönemi Tiyatrosunun Yarattı̆̆ Cinsiyetçi İmgelem”. Der. S. Sancar, Birkaç Arpa Boyu: 21. Yüzyıla Girerken Türkiye'de Feminist Çalışmalar: Prof Dr. Nermin Abadan Unat'a Armağan (2011) 680-701. İstanbul. 